\title{
Pengaruh Latihan Piramida Descending dengan irama lambat dan cepat terhadap Kekuatan, Kecepatan, Daya ledak dan Hypertropy Otot tungkai
}

\author{
Setiyo Hartoto ${ }^{a}$ \\ ${ }^{a}$ Universitas Negeri Surabaya, Surabaya, Indonesia
}

"Corresponding author: setiyohartoto@unesa.ac.id

\section{A R T ICLE INFO}

Article history:

Received 21 August 2017

Received in revised form 28 Sept 2017

Accepted 10 Oct 2017

Keywords:

Descending

Ascending

Pyramid System

Muscle

\begin{abstract}
A B S T R A C T
Related to weight training with pyramid system, in this research the researcher will focus on ascending and descending pyramid system, comparison of multiple set training with pyramid model will be done with fast and slow rhythm, rhythm comparison and pyramid drill model which will be used to know the improvement and comparison of increased strength, speed, explosive power and hypertrophy of the leg muscles. This type of research is a quasi-experimental research, using the design of "The Randomized Group Pretest-postest Design". Treatment was done for 8 weeks (two months) with exercise frequency 3 times per week. The sample was divided into 2 groups, group 1 was given a descending pyramid training using fast rhythm, group 2 was given a descending pyramid training using a slow rhythm. It is a significant influence of the descending pyramid load system with fast and slow rhythm to strength, speed and hypertrophy of the leg muscles, but not significant in explosive power for the slow rhythm descending pyramid load.
\end{abstract}

\section{Pendahuluan}

Mencapai prestasi olahraga yang tinggi sangat diperlukan berbagai peran disiplin ilmu. Pencapaian prestasi olahraga yang maksimal banyak faktor yang mempengaruhi. Mencapai prestasi olahraga yang maksimal banyak faktor yang mempengaruhi salah satunya adalah kondisi fisik, Karena dengan memiliki kemampuan fisik yang prima dapat mendukung kemampuan teknik dan taktik serta mental yang sempurna, yang pada akhirnya dapat meningkatkan prestasi. Secara umum kondisi fisik terdiri dari beberapa komponen dasar yaitu kekuatan, daya tahan, kecepatan, kelenturan dan koordinasi (Bompa, 1999).

Beberapa komponen kondisi fisik, otot tungkai merupakan salah satu komponen penting yang dibutuhkan oleh banyak cabang olahraga dinamis. Sebagai contoh dapat dilihat dalam cabang olahraga atletik nomor lari, lompat, loncat, bolavoli pada saat melakukan lompatan smash, blok, dan servis serta sepakbola pada saat melakukan tendangan. Sehubungan dengan itu, disebutkan bahwa sebagian cabang olahraga dinamis membutuhkan banyak peran otot tungkai.

Cabang olahraga dinamis seperti cabang olahraga atletik, bolavoli, bulutangkis, sepakbola dan yang lainya disebutkan membutuhkan banyak peran otot tungkai. Hal tersebut sesuai dengan pernyataan Soekarman bahwa otot tungkai dalam beberapa cabang olahraga dinamis merupakan salah satu bagian tubuh penting perannya.

Pada olahraga yang bersifat dinamis, kekuatan, kecepatan, dan daya ledak adalah aspek fisik yang paling krusial karena pada olahraga yang sifatnya dinamis banyak terdapat gerakan seperti merubah arah, akselerasi dan melompat (Newton, 1997). Semantara itu, banyak cara atau metode yang dapat digunakan untuk meningkatkan kemampuan kondisi fisik kekuatan, kecepatan, dan daya ledak otot tungkai. Salah satu bentuk latihan yang sering digunakan untuk meningkatkan kemampuan kondisi fisik tersebut diantaranya adalah latihan pliometrik, latihan speed play, interval training, dan latihan beban. Selanjutnya dijelaskan bahwa latihan beban dapat dilakukan dengan sistim super set, interval, force repetisi, negatif repetisi, circuit serta piramida.

Melakukan latihan beban dengan latihan piramida dalam kajian literatur yang dilakukan penulis terbukti dapat meingkatkan kekuatan, kecepatan, daya ledak (Ratamess,2007). Pernyataan ini berdasarkan karena latihan piramida menggunakan sistem multiple set programs yang dipercaya lebih efektif dan efisien pada latihan beban dibandingkan dengan latihan beban dengan model klasik menggunakan single set. Dari kajian literatur yang dilakukan penulis, sejak tahun 2003 terus terjadi perdebatan antara latihan multiple set piramida training dengan single set. Berbagai penelitian, salah satunya yang dilakukan oleh Munn menghasilkan bahwa multiple set piramida training lebih efektif untuk meningkatkan kekuatan dengan hasil peningkatan sebesar $48 \%$ dibandingkan dengan latihan beban dengan metode klasik single set yang hanya 25\% (Munn,2005).

Sementara itu peningkatan aspek kondisi fisik pada atlet akan membawa keadaan pada morfologi tubuh atlet berupa peningkatan massa tubuh, perubahan ukuran yang semakin besar pada satu bagian tubuh pada tubuh yang dilatih diyakini sebagai proses hypertrophy pada tubuh. Hypertrophy adalah membesarnya otot sebagai akibat dari program pelatihan beban, sehingga terjadi meningkatnya (membesarnya) penampang dari setiap sel otot (NSCA,2012). Sehingga terlihat bahwa apabila tubuh terkena tekanan dengan menggunakan latihan pembebanan, akan terjadi peningkatan massa otot dan hal ini tentu berhubungan dengan 
peningkatan kekuatan. Ronnestad melaporkan bahwa terjadi peningkatan kekuatan dan hypertrophy pada otot tubuh bagian bawah setelah melakukan latihan beban multiple set selama 11 minggu (Ronnestad,2008).

Jika dicermati, untuk mencapai satu tujuan kondisi fisik tertentu yang dibutuhkan oleh atlet, para pelatih tentu membuat periodesasi latihan yang dirancang agar kebutuhan atlet seperti kecepatan, kekuatan dan daya ledak tercapai secara bersamaan, jika melihat latihan dengan menggunakan single training maupun single set, maka dalam periodesasi tersebut tentu memakan waktu karena para pelatih harus mempersiapkan para atlet dalam memasuki satu program latihan. Sementara itu, keuntungan dari latihan beban menggunakan model piramida dapat menggunakan struktur multi set dengan beban yang dapat diatur sesuai dengan kebutuhan pelatih dan atlet dengan volume latihan yang tidak berubah.

Latihan beban piramida yang terdiri dari berbagai macam model diantaranya adalah model piramida descending atau piramida ascending. Latihan yang diawali beban ringan memberikan kesempatan pada otot-otot, sendi-sendi dan jaringan-jaringan otot menjadi lebih siap untuk mengangkat beban yang lebih berat, dan juga dengan peningkatan beban latihan akan menjadi lebih efektif untuk pembebanan otot, selain itu latihan dapat juga diberikan dengan model pemberian beban yang berat terlebih dahulu dan secara bertahap beban akan turun sesuai dengan kemampuan atlet.

Terkait dengan latihan beban dengan sistem piramida, maka dalam penelitian ini peneliti akan memfokuskan pada system model latihan piramida descending,dilakukan dengan irama cepat dan lambat, yang akan dikaitkan peningkatan kekuatan, kecepatan, daya ledak dan hypertrophy otot tungkai.

\section{Metode}

Penelitian ini bertujuan untuk menganalisis perbedaan sistem latihan beban piramida descending dengan menggunakan irama cepat dan lambat terhadap kecepatan, kekuatan, daya ledak dan hypertrophy otot tungkai. Jenis penelitian ini adalah penelitian eksperimen semu, dengan menggunakan desain "The Randomized Group Pretest-postest Design". Sampel dalam penelitian ini adalah mahasiswa jurusan kepelatihan angkatan 2013 Universitas Negeri Surabaya (UNESA) yang memiliki usia 18-20 tahun. Perlakuan dilakukan selama 8 minggu (dua bulan) dengan frekwensi latihan 3 kali tiap minggu yaitu senin, rabu, jumat dilakukan sore hari dimulai pukul 16.00-17.30 WIB di SFC UNESA, selain itu ada tambahan 2 hari untuk digunakan melakukan pretest dan postest, mengukur kecepatan, kekuatan, daya ledak dan hypertrophy otot tungkai. Sampel dibagi menjadi 2 kelompok dengan masing-masing kelompok diberi perlakuan yang berbeda, kelompok 1 diberi pelatihan piramida descending dengan menggunakan irama cepat, kelompok 2 diberikan diberi pelatihan piramida descending dengan menggunakan irama lambat,. Bentuk latihan beban yang digunakan untuk mengembangkan otot tungkai dengan jumlah 5 macam yaitu Leg Press Toe Raise, Leg Squat, Leg Extention, Leg Curl jumlah set 3 dengan istirahat 90 detik.

Untuk memperoleh data dalam penelitian ini dilakukan tes pada 2 kelompok penelitian. Tes yang di ambil adalah (1) kecepatan lari dengan melakukan tes kecepatan lari 50 meter, (2) untuk mengetahui kekuatan otot tungkai digunakan tes leg dynamometer, (3) untuk mengetahui daya ledak otot tungkai digunakan tes Accu Power Vertion 1.3, (4) untuk mengetahui hypertrophy otot tungkai dengan mengukur lingkar betis dengan meteran.

Jenis penelitian ini adalah ekperimen semu (quasi experiment), dengan pendekatan kuantitatif (quantitative research) dengan rancangan penelitian eksperimental (experimental design) yang berarti memberikan perlakuan terhadap sampel berupa model pelatihan piramida descending irama cepat dan lambat . Rancangan yg digunakan dalam penelitian ini Ramdomize Group Pretest Postest Design

\section{Hasil dan Pembahasan}

\section{a.Deskriptif Data}

Hasil tes sebelum dan sesudah diberikan latihan beban pada 10 orang mahasiswa pendidikan kepelatihan olahraga sebagai berikut.

\section{Kelompok I (Piramida Descending Irama Cepat)}

\section{Hasil Tes Hypertrophy Kelompok I}

Berdasarkan hasil pengukuran pada kelompok I dapat dilihat bahwa terdapat sebuah peningkatan nilai rerata antara pretest dan postest pada variabel dependent. Hal ini terbukti dari nilai rerata postest lebih besar daripada nilai rerata pretest. Dimana dapat kita lihat bahwa nilai rerata untuk hypertrophy kanandari hasil pengukuran postest $(35,93)$, ini terlihat lebih tinggi dibanding dengan hasil pengukuran pretest sebesar $(34,83)$. Nilai rerata untuk hypertrophy kiri dari hasil pengukuran postest $(35,90)$, ini terlihat lebih tinggi dibanding dengan hasil pengukuran pretest sebesar $(34,82)$. Hasil tersebut dapat kita ambil sebuah simpulan bahwa dalam pemberian treatment pada kelompok I seperti yang sudah dijelaskan sebelumnya, dapat meningkatkan variabel dependent.

\section{Hasil Tes Kecepatan Lari Kelompok I}

Berdasarkan hasil pengukuran pada kelompok I dapat dilihat bahwa terdapat sebuah peningkatan nilai rerata antara pretest dan postest pada variabel dependent. Hal ini terbukti dari nilai rerata postest lebih besar daripada nilai rerata pretest. Nilai rerata untuk kecepatan lari dari hasil pengukuran postest $(7,65)$, ini terlihat lebih tinggi dibanding dengan hasil pengukuran pretest sebesar $(6,77)$. Hasil tersebut dapat kita ambil sebuah simpulan bahwa dalam pemberian treatment pada kelompok I seperti yang sudah dijelaskan sebelumnya, dapat meningkatkan variabel dependent

\section{Hasil Tes Kekuatan Otot Tungkai Kelompok I}

Berdasarkan hasil pengukuran pada kelompok I dapat dilihat bahwa terdapat sebuah peningkatan nilai rerata antara pretest dan postest pada variabel dependent. Hal ini terbukti dari nilai rerata postest lebih besar daripada nilai rerata pretest. Dimana dapat kita lihat bahwa nilai rerata untuk kekuatan otot tungkai dari hasil pengukuran postest $(176,9)$, ini terlihat lebih tinggi dibanding dengan hasil pengukuran pretest sebesar $(143,8)$. Hasil tersebut dapat kita ambil sebuah simpulan bahwa dalam 
pemberian treatment pada kelompok I seperti yang sudah dijelaskan sebelumnya, dapat meningkatkan variabel dependent.

\section{Hasil Tes Daya Ledak Otot Tungkai Kelompok I}

Berdasarkan hasil pengukuran pada kelompok I dapat dilihat bahwa terdapat sebuah peningkatan nilai rerata antara pretest dan postest pada variabel dependent. Hal ini terbukti dari nilai rerata postest lebih besar daripada nilai rerata pretest. Nilai rerata untuk daya ledak otot tungkai dari hasil pengukuran postest $(88,16)$, ini terlihat lebih tinggi dibanding dengan hasil pengukuran pretest sebesar $(75,3)$. Hasil tersebut dapat kita ambil sebuah simpulan bahwa dalam pemberian treatment pada kelompok I seperti yang sudah dijelaskan sebelumnya, dapat meningkatkan variabel dependent.

\section{Kelompok II (Piramida Descending Irama Lambat)}

\section{Hasil Tes Hypertrophy Otot Tungkai Kelompok II}

Berdasarkan hasil pengukuran pada kelompok II dapat dilihat bahwa terdapat sebuah peningkatan nilai rerata antara pretest dan postest pada variabel dependent. Hal ini terbukti dari nilai rerata postest lebih besar daripada nilai rerata pretest. Dimana dapat kita lihat bahwa nilai rerata untuk hypertrophy kanan dari hasil pengukuran postest $(34,85)$, ini terlihat lebih tinggi dibanding dengan hasil pengukuran pretest sebesar $(34,38)$. Nilai rerata untuk hypertrophy kiri dari hasil pengukuran postest $(35,06)$, ini terlihat lebih tinggi dibanding dengan hasil pengukuran pretest sebesar $(34,45)$. Hasil tersebut dapat kita ambil sebuah simpulan bahwa dalam pemberian treatment pada kelompok II seperti yang sudah dijelaskan sebelumnya, dapat meningkatkan variabel dependent.

\section{Hasil Tes Kecepatan Lari Kelompok}

Berdasarkan hasil pengukuran pada kelompok II dapat dilihat bahwa terdapat sebuah peningkatan nilai rerata antara pretest dan postest pada variabel dependent.Hal ini terbukti dari nilai rerata postest lebih besar daripada nilai rerata pretest. Nilai rerata untuk kecepatan lari dari hasil pengukuran postest $(7,61)$, ini terlihat lebih tinggi dibanding dengan hasil pengukuran pretest sebesar $(6,85)$. Hasil tersebut dapat kita ambil sebuah simpulan bahwa dalam pemberian treatment pada kelompok II seperti yang sudah dijelaskan sebelumnya, dapat meningkatkan variabel dependent.

\section{Hasil Tes Kekuatan Otot Tungkai Kelompok II}

Berdasarkan hasil pengukuran pada kelompok II dapat dilihat bahwa terdapat sebuah peningkatan nilai rerata antara pretest dan postest pada variabel dependent. Hal ini terbukti dari nilai rerata postest lebih besar daripada nilai rerata pretest. Dimana dapat kita lihat bahwa nilai rerata untuk kekuatan otot tungkai dari hasil pengukuran postest $(158,95)$, ini terlihat lebih tinggi dibanding dengan hasil pengukuran pretest sebesar $(142,35)$.

Hasil Tes Daya ledak Otot Tungkai Kelompok II

Berdasarkan hasil pengukura pada kelompok II dapat dilihat bahwa terdapat sebuah peningkatan nilai rerata antara pretest dan postest pada variabel dependent. Hal ini terbukti dari nilai rerata postest lebih besar daripada nilai rerata pretest. Nilai rerata untuk daya ledak otot tungkai dari hasil pengukuran postest $(88,17)$, ini terlihat lebih tinggi dibanding dengan hasil pengukuran pretest sebesar $(74,99)$. Hasil tersebut dapat kita ambil sebuah simpulan bahwa dalam pemberian treatment pada kelompok II seperti yang sudah dijelaskan sebelumnya, dapat meningkatkan variabel dependent.

\section{Simpulan dan Rekomendasi}

Dalam penelitian ini dapat simpulan sebagai berikut :

a. Terdapat pengaruh signifikan pada latihan beban sistem piramida desceding dengan irama cepat terhadap kekuatan, kecepatan, daya ledak dan hypertrophy otot tungkai

b. Terdapat pengaruh signifikan pada latihan beban sistem piramida descending dengan irama lambat terhadap kekuatan, kecepatan dan hypertrophy otot tungkai, akan tetapi tidak signifikan pada daya ledak.

Berdasarkan hasil yang didapatkan setelah melakukan penelitian, beberapa saran yang dapat disampaikan peneliti yaitu:

Berdasarkan kesimpulan di atas maka diberikan saran sebagai berikut :

a. Dalam pelatihan olahraga untuk meningkatkan aspek hypertrophy otot tungkai kanan, hypertrophy otot tungkai kiri, dan kecepatan, kekuatan otot tungkai dan daya ledak otot tugkai lebih baik mengunakan latihan beban piramida descending irama cepat.

b. Untuk atlet binaraga yang memerlukan hypertrophy disarankan latihan beban piramida descending irama cepat dan lambat.

\section{REFERENSI}

Bompa TO, (1990) “ The Teory And Metodology Of Training, 1st Edition, Lowa”. Kirkkendall / Hunt Publising Company. pp. 1-2, 22-93, 119129.

Bompa TO, (1994) "Teory And Metodology Of Training, 2nd Edition, Lowa" Kendall / Hurt Publishing Company.

Bompa TO, (2000) "Teory And Metodology Of Training, 4nd Edition, Lowa" Kendall / Hurt Publishing Company.

Munn J dkk, (2005), Resistance training for strength effect of number of sets and contraction on speed., jounal Med Sci Sports exerc, sep 37 (9); $1622-6$

Newton,R.U., A.J. Murphy B.J. Humphries. GJ., and Wilson. (1997). "Influence of load and stretch shortening cycle on kinematics, kinetics, and muscle activation that occurs during explosive upper-body movements". European Journal Applied Physiology. (75).333-342. 
NSCA (2012). NSCA's Essentials Personal Training. United States. Human Kinetics.

Ratamess, NA, Falvo, MJ,Mangine,GT, Hoffman, JR, Faigenbaum, AD, \& Kang (2007). "The effect of rest interval length on metabolic response to the bench exercise", European journal of apllied physiology (100). $1-17$.

Ronnestal dkk (2008), Sort-term Effectc of Strenght and Plyometric Training on Sprint and Jump Performance in Profisional Soccer Player. Journal of Strenght and Conditioning Research, 22(3), 773-780.

Rosenthal N (2002) Different modes of hypertrophy in skeletal muscle fibers, journal of biology, 2002,jcn. Repress.org 